\title{
Assessment of oral and general health status in older adults
}

\author{
Hilal Eksi Ozsoy ${ }^{1}$, Sevda Atalay², Aysen Nekora Azak ${ }^{3}$
}

${ }^{1}$ Department of Prosthodontics, School of Dentistry, University of Beykent, Istanbul, Turkey

${ }^{2}$ Department of Prosthodontics, School of Dentistry, University of Okan, Istanbul, Turkey

${ }^{3}$ Department of Prosthodontics, Private Clinic, Switzerland

This work is licensed under a

Creative Commons Attribution 4.0

International License

Received: 2020-03-29

Accepted: 2020-05-01

UDC: 618.1

\section{J Clin Med Kaz 2020; 3(57):24-28}

Corresponding Author: Dr. Hilal Eksi Ozsoy, School of Dentistry, Beykent University, Cumhuriyet Street, Istanbul, TR 34550, Turkey.

E-mail: hilaleksi@gmail.com
Abstract

Introduction: The World Health Organization defines people aged 65 and over as "older adults". With the development of preventive and curative services and the decrease in fertility and mortality rates, the world population, especially in developed countries, is rapidly aging. The aim of this study was to determine the relationship between the oral-dental health profile and variables such as some socio-demographic characteristics and habits of oral health in older adults.

Material and methods: A questionnaire was used to record sociodemographic characteristics and habits of oral health, and a special examination form was used to evaluate oral health. In total, 422 patients were divided into three groups of ages $65-74,75-84$ and $85+$. The SPSS 22.0 version was used for the analysis of data.

Results: If demographic information of groups are compared, gender and educational status are not statistically significant, but marital status is statistically significant. No statistically significant difference was found between the groups in terms of nutritional content and nutritional limitation. When the questions about oral health were evaluated, a statistically significant difference was found between the groups regarding the status of removable prostheses.

Conclusion: Data related to the socio-demographic characteristics, oral health habits and general/oral health status constitute an important resource for dentists and health managers. However, further research is needed to improve the quality of life of the older adult population. The increase of such resources will be beneficial in many areas related to individual oral health care and public health management in older adults.

Key words: oral health, general health, older adults

\section{ҚАРТ АДАМДАРДА АУЫЗ ҚУЫСЫ ГИГИЕНАСЫН ЖӘНЕ ЖАЛПЫ ДЕНСАУЛЫҚ ЖАҒДАЙЫН БАҒАЛАУ} Х.Э. Озсой ${ }^{1}$, А.С. Аталай Онур ${ }^{2}$ А.Н. Азак ${ }^{3}$

'Протездеу кафедрасы, стоматология мектебі, Бейкент университеті, Ыстамбұл, Түркия

Протездеу кафедрасы, стоматология мектебі, Окан Университеті, Ыстамбұл Түркия

${ }^{3}$ Протездеу бөлімі, Жеке клиника, Швейцария

\section{ТҰЖЫРЫМДАМА}

Кіріспе: Дүниежүзілік денсаулық сақтау ұйымы 65 жастан асқан адамдарды «қарт адамдар» деп анықтайды. Алдын алу және емдеу қызметтерінің дамуы және туу мен өлім-жітімнің төмендеуімен әлем халқы, әсіресе дамыған елдерде, тез қартаюда. Бұл зерттеудің мақсаты егде жастағы адамдарда ауыз қуысының денсаулығы мен әлеуметтік-демографиялық сипаттамалары мен ауыз қуысының гигиенасы сияқты ауыспалылар арасындағы байланысты анықтау болды.

Материалдар және әдістер: Ауыз қуысының гигиенасының әлеуметтік-демографиялық сипаттамалары мен әдеттерін тіркеу үшін сауалнама жүргізіліп, ауыз қуысының жағдайын бағалау үшін арнайы сауалнама пайдаланылды. Барлығы 422 науқас үш жас тобына бөлінді: 65-74, 75-84 және 85+. Деректерді талдау үшін SPSS 22.0 нұсқасы қолданылды.

Нәтижелері: Топтар туралы демографиялық ақпаратты салыстыру кезінде жынысы мен білім мәртебесі статистикалық маңызды емес, ал неке жағдайы статистикалық маңызды. Тамақтану мазмұны мен шектеу бойынша топтар арасында статистикалық маңызды айырмашылықтар табылған жоқ. Ауыз қуысының гигиенасы мәселелерін бағалау кезінде топтар арасында алынатын протездердің жағдайына қатысты статистикалық маңызды айырмашылық анықталды.

Қорытынды: Әлеуметтік-демографриялық сипаттамаларға, ауыз қуысының гигиенасына және денсаулықтың жалпы / ауызша күйіне қатысты мәліметтер стоматологтар мен денсаулық сақтау менеджерлері үшін маңызды ресурс болып табылады. Алайда, ересек адамдардың өмір сүру сапасын жақсарту үшін қосымша зерттеулер қажет. Мұндай ресурстардың ұлғаюы жеке адамдарға арналған ауызша күтім және денсаулық сақтауды басқарумен байланысты көптеген салаларда пайдалы болады.

Негізгі сөздер: ауыз қуысының гигиенасы, денсаулықтың жалпы жағдайы, қарт адамдар 


\section{PEЗЮМЕ}

Введение: Всемирная организация здравоохранения определяет людей в возрасте 65 лет и старше как «пожилых людей». С развитием просрилактических и лечебных услуг и снижением показателей рождаемости и смертности, население мира, особенно в развитых странах быстро стареет. Цель настоящего исследования состояла в том, чтобы определить взаимосвязь между состоянием здоровья полости рта и такими переменными, как социально-демографические характеристики и привычки гигиены полости рта у пожилых людей.

Материалы и методы: Для регистрации социально-демографических характеристик и привычек гигиены полости рта использовалась анкета, а для оценки состояния полости рта использовалась специальная форма обследования. В общей сложности 422 пациента были разделены на три возрастные группы: 65-74, 75-84 и 85+. Для анализа данных была использована версия SPSS 22.0.

Результаты: Если сравнивать демографическую информацию о группах, пол и образовательный статус не являются статистически значимыми, но семейное положение статистически значимо. Статистически значимых различий между группами по содержанию и ограничению питания обнаружено не было. При оценке вопросов о гигиене полости рта, между группами было обнаружено статистически значимое различие в отношении состояния съемных протезов.

Заключение: Данные, относящиеся к социально-демографическим характеристикам, привычкам гигиены полости рта и общему состоянию/состоянию здоровья полости рта, представляют собой важный ресурс для стоматологов и руководителей здравоохранения. Тем не менее, необходимы дальнейшие исследования для улучшения качества жизни пожилого взрослого населения. Увеличение таких ресурсов будет выгодно во многих областях, связанных с индивидуальным уходом за полостью рта и управлением общественным здравоохранением для пожилых людей.

Ключевые слова: гигиена полости рта, общее состояние здоровья, пожилые люди

\section{Introduction}

Today, the responsibility of dentists is not only to treat patients but also to protect and improve oral-dental health. It is necessary to know the socioeconomic and cultural infrastructure of the society to obtain information about pre-diseases and to predict the future. Oral-dental health is an issue about which some people are unaware unless it creates a complaint. However, early tooth loss causes psychological, physiological and aesthetic problems in individuals. Studies aimed at determining the level of oral-dental health throughout the country state that the public can be informed about oral health and benefits by necessary dental services. As a result of the data obtained, measures and decisions can be taken to improve people's quality of life.

The World Health Organization defines people aged 65 and over as "older adults" [1]. With the development of preventive and curative services and the decrease in fertility and mortality rates, the world population, especially in developed countries, is rapidly aging. According to the Turkey Statistical Institute's 2018 data, the country's population over the age of $65(3.3 \%$ in 1950 ) rose to $8.8 \%$ in 2018 [2], and the proportion of older adults will increase to $10.2 \%$ in 2023 to $20.8 \%$ in 2050 and to $27.7 \%$ in 2075 [3]. With this increase in the older adult population, health and care issues related to these adults are gaining importance. The aim of this study was to determine the relationship between the oral-dental health profile and variables such as some sociodemographic characteristics and habits of oral health in older adults who had been treated at the Istanbul Aydin University, Faculty of Dentistry. The study was planned to evaluate the oral health status of the individuals using self-reports on their oral health status.

\section{Material and methods}

The study was approved by the local research ethical committee at Istanbul Aydin University, Istanbul, Turkey (ethical approval file number 2019/170). All patients agreed to participate in the research. In a retrospective study, we assessed 422 patients aged 65 and older.

A questionnaire was used to record socio-demographic characteristics and habits of oral health, and a special examination form was used to evaluate oral health. In total, 422 patients were divided into three groups of ages $65-74,75-84$ and $85+$.
The statistical software SPSS (Statistical Package for Social Sciences, Version 20, Chicago IL, USA) was used for calculations. The significance test of the difference between two means (t-test), the chi-square test and variance analysis were used to evaluate the data.

\section{Results}

The demographic data of the patients were compared among the age groups. The difference between the ratios was not statistically significant $(p=0.784)$. Similarly, the difference between the rates of "educational status" was not statistically significant $(\mathrm{p}=0.248)$. However, difference between the rates of "marital status" was statistically significant $(\mathrm{p}=0.001)$ (Table 1).

Table 1 Sociodemographic information

\begin{tabular}{|c|c|c|c|c|c|}
\hline & & \multicolumn{3}{|l|}{ Groups } & \multirow[t]{2}{*}{$\mathrm{p}$} \\
\hline & & $65-74$ & $75-84$ & $85+$ & \\
\hline \multirow[t]{4}{*}{ Gender } & \multirow[t]{2}{*}{ Woman } & 179 & 46 & 5 & \multirow[t]{4}{*}{0,784} \\
\hline & & $77,80 \%$ & $20,00 \%$ & $2,20 \%$ & \\
\hline & \multirow[t]{2}{*}{ Man } & 148 & 43 & 3 & \\
\hline & & $76,30 \%$ & $22,20 \%$ & $1,50 \%$ & \\
\hline \multirow[t]{8}{*}{ Education } & \multirow[t]{2}{*}{ Primary } & 174 & 55 & 5 & \multirow[t]{8}{*}{0,248} \\
\hline & & $74,40 \%$ & $23,50 \%$ & $2,10 \%$ & \\
\hline & \multirow[t]{2}{*}{ High school } & 55 & 17 & 1 & \\
\hline & & $75,30 \%$ & $23,30 \%$ & $1,40 \%$ & \\
\hline & \multirow[t]{2}{*}{ University } & 76 & 10 & 1 & \\
\hline & & $87,40 \%$ & $11,50 \%$ & $1,10 \%$ & \\
\hline & \multirow[t]{2}{*}{ Illiterate } & 17 & 7 & 1 & \\
\hline & & $68,00 \%$ & $28,00 \%$ & $4,00 \%$ & \\
\hline \multirow{4}{*}{$\begin{array}{l}\text { Marital } \\
\text { Status }\end{array}$} & \multirow[t]{2}{*}{ Not Married } & 92 & 37 & 6 & \multirow[t]{4}{*}{0,001} \\
\hline & & $68,10 \%$ & $27,40 \%$ & $4,40 \%$ & \\
\hline & \multirow[t]{2}{*}{ The married } & 234 & 51 & 2 & \\
\hline & & $81,50 \%$ & $17,80 \%$ & $0,70 \%$ & \\
\hline
\end{tabular}

Table 2 showed that the difference between the ratios of having any general health problems and using medicals was not statistically significant $(\mathrm{p}=0.230,0,756)$.

When the questions about oral health care were examined for 3 groups, the difference between the rates of "visiting dentist" 
Systemic diseases and using of drug order

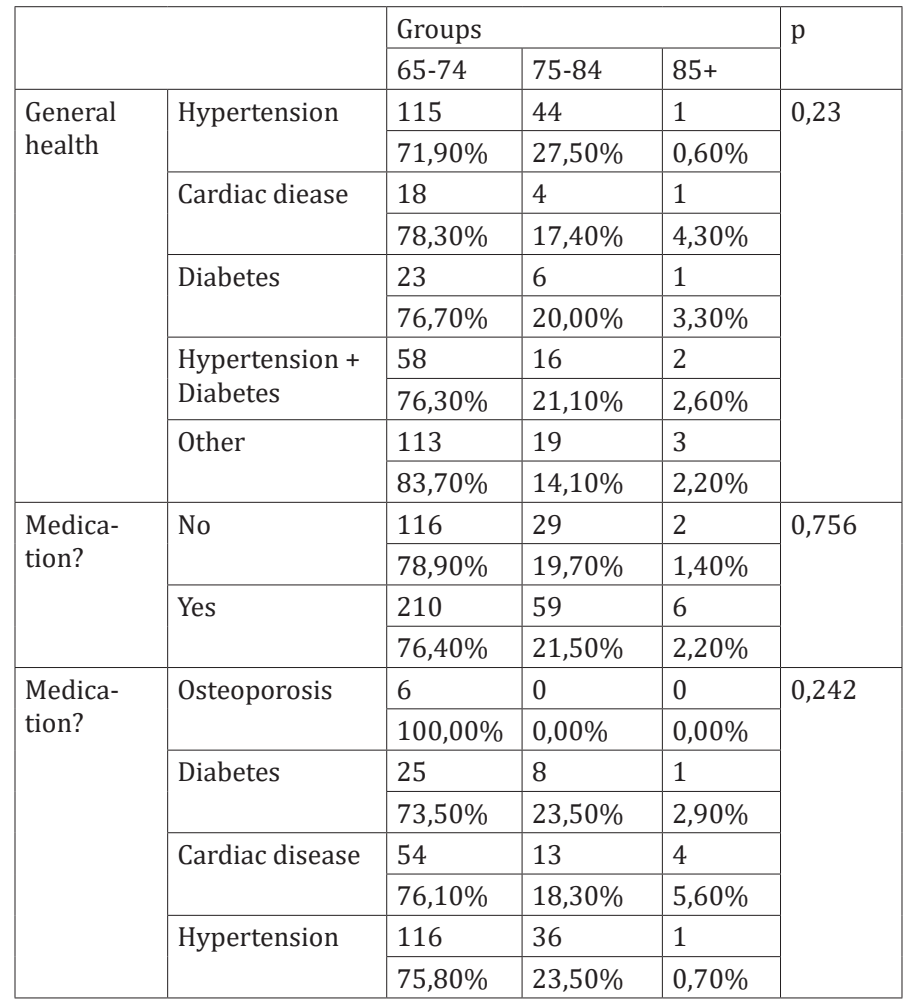

and "brushing teeth" were statistically significant $(\mathrm{p}=0.357$ and $\mathrm{p}=0.381$ ). However, the difference between the rates of "using dental floss" was not statistically significant $(\mathrm{p}=0.310)$ (Table 3$)$.

The pain in the mouth or jaw joint were evaluated. While the difference between the rates of "pain in the mouth" was statistically significant $(p=0.444)$, the difference between the rates of "pain in the jaw joint" was not statistically significant $(p=0.394)$ The difference between the ratios of "Nutritional content" and "Restriction in diet" was not statistically significant $(\mathrm{p}=0.885$ and $\mathrm{p}=0.303)$ (Table 4).

The smoking and using alcohol were also evaluated for 3 groups. The difference between the ratios of both "use of smoking" and "use of alcohol" was statistically significant $(\mathrm{p}=0.292$ and $\mathrm{p}=0.180)$ (Table 5).

The presence and current status of the teeth or dentures were examined. Only, the difference between the ratios of "Removable prosthesis" was statistically significant $(\mathrm{p}=0.202)$. The difference between the ratios of "Teeth", "Hygiene",
Table 3

Care of oral health status

\begin{tabular}{|c|c|c|c|c|c|}
\hline & & \multicolumn{3}{|l|}{ Groups } & \multirow[t]{2}{*}{$\mathrm{p}$} \\
\hline & & $65-74$ & $75-84$ & $85+$ & \\
\hline \multirow{4}{*}{$\begin{array}{l}\text { Visiting } \\
\text { dentist }\end{array}$} & \multirow[b]{2}{*}{ Once a year } & 66 & 17 & 0 & \multirow[t]{4}{*}{0,357} \\
\hline & & $79,50 \%$ & $20,50 \%$ & $0,00 \%$ & \\
\hline & \multirow[t]{2}{*}{ If there is pain } & 255 & 68 & 8 & \\
\hline & & $77,00 \%$ & $20,50 \%$ & $2,40 \%$ & \\
\hline \multirow[t]{8}{*}{ Brushing } & \multirow[t]{2}{*}{ 2-3 times a day } & 141 & 36 & 6 & \multirow[t]{8}{*}{0,381} \\
\hline & & $77,00 \%$ & $19,70 \%$ & $3,30 \%$ & \\
\hline & \multirow[t]{2}{*}{ Only morning } & 39 & 11 & 1 & \\
\hline & & $76,50 \%$ & $21,60 \%$ & $2,00 \%$ & \\
\hline & \multirow[t]{2}{*}{ Only night } & 87 & 17 & 0 & \\
\hline & & $83,70 \%$ & $16,30 \%$ & $0,00 \%$ & \\
\hline & \multirow{2}{*}{$\begin{array}{l}\text { when it comes } \\
\text { to mind }\end{array}$} & 42 & 12 & 0 & \\
\hline & & $77,80 \%$ & $22,20 \%$ & $0,00 \%$ & \\
\hline \multirow{4}{*}{ Flossing } & \multirow[t]{2}{*}{ use } & 39 & 6 & 0 & \multirow[t]{4}{*}{0,31} \\
\hline & & $86,70 \%$ & $13,30 \%$ & $0,00 \%$ & \\
\hline & \multirow[t]{2}{*}{ No-use } & 276 & 77 & 8 & \\
\hline & & $76,50 \%$ & $21,30 \%$ & $2,20 \%$ & \\
\hline
\end{tabular}

Table 4 Presence of pain and nutritional status

\begin{tabular}{|c|c|c|c|c|c|}
\hline & & \multicolumn{3}{|l|}{ Groups } & \multirow[t]{2}{*}{$\mathrm{p}$} \\
\hline & & $65-74$ & $75-84$ & $85+$ & \\
\hline \multirow{4}{*}{$\begin{array}{l}\text { Pain in } \\
\text { mouth? }\end{array}$} & \multirow[t]{2}{*}{ Yes } & 28 & 5 & 0 & \multirow[t]{4}{*}{0,444} \\
\hline & & $84,80 \%$ & $15,20 \%$ & $0,00 \%$ & \\
\hline & \multirow[t]{2}{*}{ No } & 290 & 83 & 8 & \\
\hline & & $76,10 \%$ & $21,80 \%$ & $2,10 \%$ & \\
\hline \multirow{4}{*}{$\begin{array}{l}\text { Pain in Jaw } \\
\text { Joint? }\end{array}$} & \multirow[t]{2}{*}{ Yes } & 25 & 10 & 0 & \multirow[t]{4}{*}{0,394} \\
\hline & & $71,40 \%$ & $28,60 \%$ & $0,00 \%$ & \\
\hline & \multirow[t]{2}{*}{ No } & 294 & 78 & 8 & \\
\hline & & $77,40 \%$ & $20,50 \%$ & $2,10 \%$ & \\
\hline \multirow[t]{6}{*}{ Diet } & \multirow{2}{*}{$\begin{array}{l}\text { Protein- } \\
\text { Carbohydrate }\end{array}$} & 36 & 10 & 1 & \multirow[t]{6}{*}{0,885} \\
\hline & & $76,60 \%$ & $21,30 \%$ & $2,10 \%$ & \\
\hline & \multirow[t]{2}{*}{ Vegetable } & 78 & 26 & 2 & \\
\hline & & $73,60 \%$ & $24,50 \%$ & $1,90 \%$ & \\
\hline & \multirow{2}{*}{$\begin{array}{l}\text { I do not eat } \\
\text { balanced }\end{array}$} & 209 & 52 & 5 & \\
\hline & & $78,60 \%$ & $19,50 \%$ & $1,90 \%$ & \\
\hline \multirow{4}{*}{$\begin{array}{l}\text { Restriction } \\
\text { in diet }\end{array}$} & \multirow[t]{2}{*}{ No } & 248 & 61 & 5 & \multirow[t]{4}{*}{0,303} \\
\hline & & $79,00 \%$ & $19,40 \%$ & $1,60 \%$ & \\
\hline & \multirow[t]{2}{*}{ Yes } & 72 & 25 & 3 & \\
\hline & & $72,00 \%$ & $25,00 \%$ & $3,00 \%$ & \\
\hline
\end{tabular}

\section{Table 5}

Using of smoking and alcohol

\begin{tabular}{|c|c|c|c|c|c|}
\hline & & \multicolumn{3}{|l|}{ Groups } & \multirow{2}{*}{$\mathrm{p}$} \\
\hline & & $65-74$ & $75-84$ & $85+$ & \\
\hline \multirow[t]{6}{*}{ Smoke } & \multirow[t]{2}{*}{ I've never used } & 197 & 59 & 6 & \multirow[t]{6}{*}{0,292} \\
\hline & & $75,20 \%$ & $22,50 \%$ & $2,30 \%$ & \\
\hline & \multirow[t]{2}{*}{ I use } & 60 & 9 & 0 & \\
\hline & & $87,00 \%$ & $13,00 \%$ & $0,00 \%$ & \\
\hline & \multirow[t]{2}{*}{ I left } & 66 & 18 & 2 & \\
\hline & & $76,70 \%$ & $20,90 \%$ & $2,30 \%$ & \\
\hline \multirow[t]{4}{*}{ Alcohol } & \multirow[t]{2}{*}{ No } & 281 & 81 & 8 & \multirow[t]{4}{*}{0,18} \\
\hline & & $75,90 \%$ & $21,90 \%$ & $2,20 \%$ & \\
\hline & \multirow[t]{2}{*}{ Yes } & 37 & 5 & 0 & \\
\hline & & $88,10 \%$ & $11,90 \%$ & $0,00 \%$ & \\
\hline
\end{tabular}




\begin{tabular}{|c|c|c|c|c|c|}
\hline & \multicolumn{3}{|l|}{ Groups } & \multirow[t]{2}{*}{$\mathrm{p}$} \\
\hline & & $65-74$ & 75-84 & $85+$ & \\
\hline \multirow[t]{10}{*}{ Teeth } & \multirow[t]{2}{*}{ No-teeth } & 85 & 31 & 4 & \multirow[t]{10}{*}{0,202} \\
\hline & & $70,80 \%$ & $25,80 \%$ & $3,30 \%$ & \\
\hline & Upper no & 19 & 3 & 1 & \\
\hline & Lower yes & $82,60 \%$ & $13,00 \%$ & $4,30 \%$ & \\
\hline & \multirow[t]{2}{*}{ I don't know } & 51 & 11 & 0 & \\
\hline & & $82,30 \%$ & $17,70 \%$ & $0,00 \%$ & \\
\hline & Lower no & 9 & 4 & 1 & \\
\hline & Upper yes & $64,30 \%$ & $28,60 \%$ & $7,10 \%$ & \\
\hline & \multirow{2}{*}{$\begin{array}{l}\text { Lower and } \\
\text { Upper missing } \\
\text { teeth }\end{array}$} & 149 & 32 & 2 & \\
\hline & & $81,40 \%$ & $17,50 \%$ & $1,10 \%$ & \\
\hline \multirow{6}{*}{$\begin{array}{l}\text { Removable } \\
\text { prosthesis }\end{array}$} & \multirow[t]{2}{*}{ Yes - good } & 157 & 48 & 6 & \multirow[t]{6}{*}{0,028} \\
\hline & & $74,40 \%$ & $22,70 \%$ & $2,80 \%$ & \\
\hline & \multirow[t]{2}{*}{ Yes - Not good } & 49 & 20 & 2 & \\
\hline & & $69,00 \%$ & $28,20 \%$ & $2,80 \%$ & \\
\hline & \multirow[t]{2}{*}{ No } & 107 & 17 & 0 & \\
\hline & & $86,30 \%$ & $13,70 \%$ & $0,00 \%$ & \\
\hline \multirow[t]{6}{*}{ Hygiene } & \multirow[t]{2}{*}{ Good } & 187 & 60 & 7 & \multirow[t]{6}{*}{0,077} \\
\hline & & $73,60 \%$ & $23,60 \%$ & $2,80 \%$ & \\
\hline & \multirow[t]{2}{*}{ Bad } & 25 & 8 & 1 & \\
\hline & & $73,50 \%$ & $23,50 \%$ & $2,90 \%$ & \\
\hline & \multirow[t]{2}{*}{ No - prosthesis } & 102 & 17 & 0 & \\
\hline & & $85,70 \%$ & $14,30 \%$ & $0,00 \%$ & \\
\hline \multirow[t]{4}{*}{ Caries } & \multirow[t]{2}{*}{ Yes } & 34 & 3 & 0 & \multirow[t]{4}{*}{0,81} \\
\hline & & $91,90 \%$ & $8,10 \%$ & $0,00 \%$ & \\
\hline & \multirow[t]{2}{*}{ No } & 283 & 82 & 8 & \\
\hline & & $75,90 \%$ & $22,00 \%$ & $2,10 \%$ & \\
\hline \multirow{4}{*}{$\begin{array}{l}\text { Crown } \\
\text { prosthesis }\end{array}$} & \multirow[t]{2}{*}{ Yes } & 120 & 26 & 3 & \multirow[t]{4}{*}{0,482} \\
\hline & & $80,50 \%$ & $17,40 \%$ & $2,00 \%$ & \\
\hline & \multirow[t]{2}{*}{ No } & 195 & 58 & 5 & \\
\hline & & $75,60 \%$ & $22,50 \%$ & $1,90 \%$ & \\
\hline \multirow{4}{*}{$\begin{array}{l}\text { Bridge } \\
\text { prosthesis }\end{array}$} & \multirow[t]{2}{*}{ Yes } & 141 & 26 & 4 & \multirow[t]{3}{*}{0,067} \\
\hline & & $82,50 \%$ & $15,20 \%$ & $2,30 \%$ & \\
\hline & No & 174 & 58 & 4 & \\
\hline & & $73,70 \%$ & $24,60 \%$ & $1,70 \%$ & \\
\hline
\end{tabular}

\begin{tabular}{|c|c|c|c|c|c|}
\hline & \multicolumn{3}{|l|}{ Groups } & \multirow[t]{2}{*}{$\mathrm{p}$} \\
\hline & & $65-74$ & 75-84 & $85+$ & \\
\hline \multirow{4}{*}{$\begin{array}{l}\text { Gingival } \\
\text { disease }\end{array}$} & \multirow[t]{2}{*}{ yes } & 41 & 8 & 0 & \multirow[t]{4}{*}{0,391} \\
\hline & & $83,70 \%$ & $16,30 \%$ & $0,00 \%$ & \\
\hline & \multirow[t]{2}{*}{ no } & 274 & 76 & 8 & \\
\hline & & $76,50 \%$ & $21,20 \%$ & $2,20 \%$ & \\
\hline \multirow{4}{*}{$\begin{array}{l}\text { Bleeding } \\
\text { gums }\end{array}$} & \multirow[t]{2}{*}{ yes } & 43 & 7 & 0 & \multirow[t]{4}{*}{0,24} \\
\hline & & $86,00 \%$ & $14,00 \%$ & $0,00 \%$ & \\
\hline & \multirow[t]{2}{*}{ no } & 273 & 77 & 8 & \\
\hline & & $76,30 \%$ & $21,50 \%$ & $2,20 \%$ & \\
\hline \multirow[t]{4}{*}{ Calculus } & \multirow[t]{2}{*}{ yes } & 42 & 8 & 0 & \multirow[t]{4}{*}{0,365} \\
\hline & & $84,00 \%$ & $16,00 \%$ & $0,00 \%$ & \\
\hline & \multirow[t]{2}{*}{ no } & 274 & 76 & 8 & \\
\hline & & $76,50 \%$ & $21,20 \%$ & $2,20 \%$ & \\
\hline \multirow{4}{*}{$\begin{array}{l}\text { Wound in } \\
\text { mouth }\end{array}$} & \multirow[t]{2}{*}{ yes } & 12 & 4 & 0 & \multirow[t]{4}{*}{0,78} \\
\hline & & $75,00 \%$ & $25,00 \%$ & $0,00 \%$ & \\
\hline & \multirow[t]{2}{*}{ no } & 304 & 80 & 8 & \\
\hline & & $77,60 \%$ & $20,40 \%$ & $2,00 \%$ & \\
\hline \multirow{4}{*}{$\begin{array}{l}\text { Wound on } \\
\text { lips }\end{array}$} & \multirow[t]{2}{*}{ yes } & 7 & 4 & 0 & \multirow[t]{4}{*}{0,404} \\
\hline & & $63,60 \%$ & $36,40 \%$ & $0,00 \%$ & \\
\hline & \multirow[t]{2}{*}{ no } & 309 & 81 & 8 & \\
\hline & & $77,60 \%$ & $20,40 \%$ & $2,00 \%$ & \\
\hline \multirow{4}{*}{$\begin{array}{l}\text { Lesion on } \\
\text { tongue }\end{array}$} & \multirow[t]{2}{*}{ yes } & 8 & 3 & 0 & \multirow[t]{4}{*}{0,779} \\
\hline & & $72,70 \%$ & $27,30 \%$ & $0,00 \%$ & \\
\hline & \multirow[t]{2}{*}{ no } & 308 & 81 & 8 & \\
\hline & & $77,60 \%$ & $20,40 \%$ & $2,00 \%$ & \\
\hline
\end{tabular}

"Caries", "Crown prosthesis", "Bridge prosthesis" was not statistically significant $(p=0.028, p=0.077, p=0.810, p=0.482$, $\mathrm{p}=0.067$ ) (Table 6).

The presence and current status of the teeth or dentures were examined. The difference between the ratios of "gingival disease", "gingival bleeding", "dental calculus", "mouth wound", "wounds at the junction of the lips" and "tongue lesions" was not statistically significant $(\mathrm{p}=0.391, \mathrm{p}=0.240$, $\mathrm{p}=0.365, \mathrm{p}=0.780, \mathrm{p}=0.404, \mathrm{p}=0.779)$ (Table 7).

\section{Discussion}

The number of women in the world population is higher than the number of men. According to Turkey's statistical agency data, between 1935 and 2018, the percentage of women over 65 was also higher than that of men [3]. In our study, although the distribution of women over the age of 65 was higher, there was a homogenous distribution.

Of the world population, 960 million people are illiterate, and 700 million of these are women, making illiterate women the majority [4]. In our study, the total number of illiterate people was $25(5.92 \%)$, and in all three groups, the education level of the majority was at the level of "primary education" (55.45\%). As to marital status, the majority of older women were widows.

In many countries, $10-20 \%$ of men over 65 and more than half of women in the same age group are widowers or widows. The reason for this is both that men die at a younger age than women, and widowed men have more marriages [4]. In our study, the number of unmarried people increased with age. Especially in individuals over 85 years of age, more people reported being unmarried than married.

The fact that the majority of the older adult population experience chronic diseases negatively affects their quality

of life. The prevalence of hypertension varies depending on geographical, cultural, demographic, nutritional and genetic factors, but it is increasing in people all over the world [5]. The frequency of hypertension, especially systolic hypertension, also increases with age, while there is no change in the diagnostic criteria of hypertension according to age. Therefore, the geriatric age group is the most common age group with hypertension [6]. There was a total of 234 people (55.49\%) with hypertension and with diabetes associated with hypertension in individuals older than 65 years.

Cardiovascular disease, one of the many diseases affecting older adults, is the main cause of disability and death [7]. In our study, although heart disease was reported in only 23 of 422 patients, 71 people reported the use of heart disease medication. The reason for this was determined to be that older adults routinely use blood thinners; irrational drug use is a common health problem in geriatric patients. Age-related pharmacodynamic-pharmacokinetic changes are a condition that should also be considered in the treatment and drug administration of these patients [8]. In our study, when asked about general systemic diseases, all individuals reported at least one disease, and 264 people were using drugs $(62.55 \%)$. Diabetes 
is a common systemic disease in the community. The prevalence rates of diabetes clearly increase with age [9]. The presence of diabetes and hypertension with diabetes was observed in 102 people $(24.17 \%)$. Consumption of high carbohydrate and fatty foods along with a sedentary lifestyle is one of the important causes of the increased frequency of diabetes [9]. In our study, individuals in all three older adult groups stated that they did not eat a balanced diet $(63.03 \%)$.

Some studies show that the prevalence of root caries is higher in older adults than in those of other ages [10]. However, the presence of caries in patient self-reports can often be determined by reports of pain. Studies have reported that the presence of pain in general health is one of the major problems affecting quality of life and that inadequate treatment is generally applied [11]. In our study, when the pain in the oral and jaw joints was examined, the notification of individuals was low. Only 37 people reported the presence of caries, and there were no reports in the 85-year-old group.

In older individuals, the number of missing teeth was greater and accounted for almost the entire number of the decayed, missing, and filled teeth (DMFT) index. Of this age group, $48.0 \%$ were edentulous [12]. In our study, a total of 165 individuals reported being edentulous (39.09\%). When asked about the presence of crowns, bridges and removable prostheses, most of the patients chose "yes." Sixty-two individuals were not aware of the presence of teeth. When asked about the status of the removable prostheses, the majority of individuals reported it as good. Similarly, the hygiene status of the prostheses was often described as good.

In older adults, the inadequacy of tooth-brushing effectiveness can be explained by low education levels and the presence of conditions that negatively affect manipulation ability, such as musculoskeletal diseases [12]. The habit of brushing 2-3 times a day was determined in 183 people $(43 \%)$, but flossing was found to be inadequate. The majority reported the frequency of their visits to the dentist as "in the presence of pain." All individuals over 85 years of age went to the dentist only in the presence of pain. Routine dental controls were neglected. Although studies have reported poor health periodontal status in older adults [13], in our study, individuals frequently reported the "none" response to the presence of calculus, gingival disease and gum bleeding. This may be due to the difference between clinical examination and patient awareness.

The negative health effects of smoking are reported extensively in the literature. However, in older adults, the effects of smoking are less clear and subject to some debate [14]. In the literature, lower consumption rates are reported in older adults. In our study, the majority of older adults reported that they had never smoked or had quit smoking. They provided a similar response about the use of alcohol.

\section{Conclusion}

Data related to the socio-demographic characteristics, oral health habits and general/oral health status constitute an important resource for dentists and health managers. However, further research is needed to improve the quality of life of the older adult population. The increase of such resources will be beneficial in many areas related to individual oral health care and public health management in older adults.

Disclosures: There is no conflict of interest for all authors.

\section{References}

1. WHOExpert Committee Health of elderly. Geneva World Health Organization. 1989. https://apps.who.int/iris/handle/10665/39521,

2. TurkStat Elderly Statistics. Turkish Statistical Institute. 2018. htpp:// www.tuik.gov.tr/UstMenu.do?metod=temelist,

3. Guler N, Guler Z, Ozsel D. Ageing in The Rural Area: Quality Of Life And Associated Factors in Sivas/Turkey. Turkish Journal of Geriatrics. 2016; 19(4):245-252.

4. Mandiracioglu A. Demographic characteristics of the elderly population in Turkey and the world. Ege Journal of Medicine. 2010; 49(3):39-45.

5. Yardimci H, Ozcelik AO, Surucuoglu MS. The status of hypertension of elderly people and their nutritional habits. Ankara Journal of Medicine. 2012; 1(2):17-36.

6. Hymen DJ, Pavlik VN. Characteristics of patients with uncontrolled hypertension in the United States. $N$ Engl J Med. 2001; 345:479-86. https://doi.org/10.1056/NEJMoa010273

7. Kashyap M.L. Cardiovascular Disease in the Elderly: Current Considerations. Am J Cardiol. 1989; 63:3-4. https://doi. org/10.1016/0002-9149(89)90107-0

8. Bilgener E., Ozcelikay G. Rational drug use in geriatric woman. Turkish Journal of Clinics. 2019; 1:62-8.

9. Assmann G., H. Schulte. The Prospective Cardiovascular Münster (PROCAM) study: Prevalence of hyperlipidemia in persons with hypertension and/or diabetes mellitus and the relationship to coronary heart disease. Am. Heart J. 1988; 116(6):1713-1724. https://doi.org/10.1016/0002-8703(88)90220-710.

10. Kitamura W, Kiyak A.H., Muiligan K. Predictors of root caries in the elderly. Geriodontics Community Dent Oral Epidemiol. 1986; 14:34-8. https://doi.org/10.1111/j.1600-0528.1986.tb01491.x

11. Projects S. and Society A.G. The Management of Persistent Pain in Older Persons AGS Panel on Persistent Pain in Older Persons. J Am Geriatr Soc. 2002; 50:205-224. https://doi.org/10.1046/j.1532-5415.50.6s.1.x

12. Gokalp P. S, Bahar P, Dogan G, Tekcicek D. M. The Oral Health Profile of Adults and Elderly, Turkey-2004. Hacettepe Journal of Medicine. 2007; 31(4):11-18.

13. Eren G, Kose T., Atilla G. Determining the oral health status and oral hygiene habits of the elderly. Samsun Journal of Medicine. $2011 ; 20: 84-94$.

14. Colleen J.M., John P.H. The Prevelans of Smoking and İmplications for Quality of Life Among the Community-Based Elderly. Am J Pre. Med. 1996; 9(3): 338-345. https://doi.org/10.1016/S0749-3797(18)30685-8

How to cite this article: Hilal Eksi Ozsoy, Aygul Sevda Atalay Onur, Aysen Nekora Azak. Assessment of oral and general health status in older adults. J Clin Med Kaz. 2020; 3(57):24-28 